\title{
Sclerotinia-Induced Accumulation of Protein in the Basal Stem of Resistant and Susceptible Lines of Sunflower
}

\author{
Robab DAVAR ${ }^{1}$, Reza DARVISHZADEH ${ }^{2,3}$, Ahmad MAJD $^{4}$ \\ ${ }^{1}$ Payame Noor University, Faculty of Science, Department of Biology, Po Box 19395-3697 Tehran, Iran; Davar.Robab@gmail.com \\ ${ }^{2}$ Urmia University, Department of Agronomy and Plant Breeding, Urmia, Iran \\ ${ }^{3}$ Urmia University, Institute of Biotechnology, Urmia, Iran \\ ${ }^{4}$ Tarbiat Moallem University, Faculty of Science, Department of Biology, Tehran, Iran
}

\begin{abstract}
Sunflower, Helianthus annuus L. is a major oilseed crop widely cultivated across the globe. White mold, caused by the necrotrophic pathogen Sclerotinia sclerotiorum (Lib.) de Bary, is a common and widespread pathogen of sunflower. Changes in a partially resistant and a susceptible sunflower line infected with Sclerotinia sclerotiorum were studied 12, 24 and $48 \mathrm{~h}$ after inoculation. Electrophoretic patterns and quantitative changes in soluble proteins were determined in the basal stem region. Soluble proteins were accumulated post infection in the partially resistant line. A rapid accumulation of stress-related, low molecular weight proteins was induced in both lines by different pathways. By 12 and $24 \mathrm{~h}$ post inoculation, stress proteins with molecular masses of $27 \mathrm{kDa}$ had accumulated in infected stems of the partially resistant line. SDS-PAGE results showed the accumulation of proteins with a molecular mass of $55 \mathrm{kDa}$ in the susceptible line and the absence of this band in the resistant line. This relatively faster response to Sclerotinia sclerotiorum invasion could be partially responsible for the resistance or susceptibility to this pathogen. The differences between lines may also indicate further avenues worth exploring in host-pathogen relations which could ultimately lead to selection and production of new lines with higher levels of resistance to Sclerotinia sclerotiorum.
\end{abstract}

Keywords: Helianthus annuus L., low-molecular-weight proteins, Sclerotinia sclerotiorum, SDS-PAGE, soluble proteins

\section{Introduction}

Sunflower, Helianthus annuus L., is one of the major plant oil crops and is widely cultivated around the world. White mold, caused by the necrotrophic fungus Sclerotinia sclerotiorum (Lib.) de Bary, is one of the most devastating and cosmopolitan soilborne plant pathogens, and infects over 500 species of plants worldwide including important field crops, fruit crops, ornamentals, trees, shrubs and numerous weeds (Saharan and Mehta, 2008). White rot caused by Sclerotinia sclerotiorum is a major yield-limiting disease of sunflower in the temperate regions of the world. The fungus can attack several plant parts and cause stalk rot/wilt or head rot (Gulya et al., 1997). Rapid drying of the leaves and development of lesions on the tap roots and basal portions of the stem cause plants to die within a few days after the onset of wilting (Dorrell and Huang, 1978). Yield losses can reach up to $100 \%$ when weather conditions are favorable for the fungus (Sackston, 1992). In Iran, infections of the sunflower basal stem are considered a potential threat to the entire crop.

To date, sunflower genotypes with different levels of resistance to stem rot have been identified, but no fully resistant genotypes are available (Davar et al., 2010), and so breeding resistant varieties is an important objective. Dif- ferent features, related to the resistance mechanisms of the plant could be applied for screening the host genotypes (Bazzalo et al., 1991).

Plants possess both pre-formed and inducible mechanisms for resisting pathogen invasion. Extant morphological barriers, secondary metabolites (phytoanticipins), and antimicrobial proteins must be avoided or overcome if pathogens are to successfully invade a plant (Slusarenko et al., 2000). Resistance, according to Agrios (1988) is the ability of an organism to exclude or overcome, completely or in some degree, the effect of a pathogen or other damaging factor. Once contact has been established, elicitors produced and released by the pathogen induce further defenses, comprising the reinforcement of cell walls, the production of phytoalexins, and the synthesis of defenserelated proteins (Slusarenko et al., 2000). Defense related genes encode a variety of proteins including enzymes controlling secondary metabolism, pathogenesis related (PR) proteins and regulatory proteins that control the expression of other defense related genes (Dixon et al., 1994).

The induced resistance response of plants to diseases correlates intimately with the accumulation of PR proteins. Pathogenesis-related proteins degrade the fungal cell wall and cause lysis of the fungal cell. Chitin and glucan oligomers released during degradation of fungal cell walls 
120

act as elicitors that elicit various defense mechanisms in plants (Frindlender et al., 1993). PR proteins are localized in extracellular regions. When plant pathogenic microorganisms invade plants, they initially multiply in the intercellular spaces of the plant cells. Therefore, the accumulation of antimicrobial proteins in the intercellular space is important for their antimicrobial ability to inhibit the invading pathogens (Lee et al., 2008).

PR proteins represent major quantitative changes in soluble protein during the defense response and usually are monomers with a low molecular mass $(8-50 \mathrm{kDa})$ (Stintzi et al., 1993).

Induction and accumulation of soluble defense proteins make the plant resistant to pathogen invasion (Van Loon, 1997), and have been correlated with defense against pathogen invasion in many plants, such as cucumber (Rasmussen, 1991), green gram (Ramanathan et al., 2000), tobacco (Beaudoin-Eagan and Thorpe, 1985) and tomato (Bashan et al., 1985).

Zhao et al. (2007) showed the enhanced accumulation of PR proteins in response to Sclerotinia sclerotiorum in Brassica napus. Low molecular pathogen-related protein was also isolated from Helianthus annuus flowers by its ability to inhibit the germination of fungal spores (Marcela et al., 2000).

In this study, is been examined whether a susceptible and a partially resistant line of sunflower responded differently to Sclerotinia sclerotiorum infection through differential protein accumulation and electrophoretic patterns of the total soluble proteins in the basal stem of infected and noninfected plants. Also is been studied the relationship between the accumulation of stress soluble proteins and the development of induced resistance in susceptible and partially resistant lines.

\section{Materials and methods}

Plant material, fungal isolate and Experimental design

Two sunflower lines, C71 and C146, identified as partially resistant and susceptible respectively to isolate SSU107 of Sclerotinia sclerotiorum in previous experiments (Davar et al., 2010), were used to study any change in electrophoretic patterns of the total soluble proteins of sunflower during the infection process. Seeds were surface sterilized in $2 \% \mathrm{NaOCl}$ for $3 \mathrm{~min}$, washed three times in sterile distilled water, and sown in $10 \times 12 \mathrm{~cm}$ pots filled with sterilized soil collected from the research farm of Urmia University, Iran. The soil was a silty clay with a $\mathrm{pH}$ of 7.6 and an EC of $0.6 \mathrm{dSm}^{-1}$. Tab. 1 summarizes the properties of the soil used in the experiments. Plants were grown for 4 weeks in a controlled environment at temperatures of $24 \pm 1^{\circ} \mathrm{C}, 65 \%$ relative humidity, and a $12 \mathrm{~h}$ photoperiod with light intensity of $200 \mu \mathrm{Em}^{2} \mathrm{~s}^{-1}$, until plants were at growth stage V6 to V8 (at least six to eight leaves on a plant) (Schneiter and Miller, 1981).

Isolate SSU107 was cultured on PDA (Potato Dextrose Agar $\left(39 \mathrm{~g} \mathrm{l}^{-1}, \mathrm{pH} 6\right)$ medium and grown in the dark at room temperature $\left(25^{\circ} \mathrm{C}\right)$. At the $\mathrm{V} 6$ to $\mathrm{V} 8$ growth stage, mycelial plugs ( $3 \mathrm{~mm}$ diameter) of isolate SSU107 were cut from the growing edge of 3 day old colonies and were placed against the basal stem of the sunflower plants. The stem and mycelial plug were wrapped with Parafilm for $48 \mathrm{~h}$ to maintain humidity, following the method of Price and Colhoun (1975). The experimental design was completely randomized with three replications. Fresh sunflower basal stem samples of inoculated and control plants were harvested 12, 24 and $48 \mathrm{~h}$ post inoculation. Samples were frozen in liquid nitrogen and then stored at $-80^{\circ} \mathrm{C}$ until biochemical assays could be performed.

\section{Protein extraction}

The frozen stem samples were ground to a fine powder in liquid nitrogen and total protein extracted with icecold $0.1 \mathrm{M}$ Tris $\mathrm{HCl}$ buffer $(\mathrm{pH} 7.5)$ containing $5 \%(\mathrm{w} / \mathrm{v})$ PVP (4:1 buffer volume:fresh weight). The homogenate was centrifuged at $13000 \mathrm{~g}$ for $15 \mathrm{~min}$ at $4^{\circ} \mathrm{C}$, and the supernatant containing the soluble stem proteins was used for determining protein concentration and SDS-PAGE analysis (Abedi et al., 2011).

\section{Quantitation of protein using the Bradford assay}

The protein concentration was spectrophotometrically determined at $595 \mathrm{~nm}$ using the Protein Assay Dye Reagent Concentrate (BioRad) according to Bradford's method (1976). Bovine serum albumin was used as standard reference in this investigation (Stoscheck, 1992).

\section{Sodium dodecyl sulfate polyacrylamide gel electrophoresis (SDS-PAGE)}

Flat bed SDS-PAGE was performed with a vertical BioRad System. Was prepared a $100 \times 70 \times 0.5 \mathrm{~mm}$ dimension acrylamide gel. Protein samples were separated on $12 \%$ SDS- PAGE gels. Prior to electrophoresis, samples were mixed with SDS sample buffer $(62.5 \mathrm{mM}$ Tris- $\mathrm{HCl}$, $\mathrm{pH} 6.8,2 \%[\mathrm{w} / \mathrm{v}]$ SDS, $10 \%[\mathrm{w} / \mathrm{v}]$ glycerol, $5 \%[\mathrm{v} / \mathrm{v}]$ $\beta$-mercaptoethanol, $0.001 \%$ [w/v] bromophenol blue) and boiled for $5 \mathrm{~min}$. The running buffer was prepared according to Garfin (1990). The buffer system in the strips

Tab. 1. Some physical and chemical properties of the soil used in this study (average values)

\begin{tabular}{|c|c|c|c|c|c|c|c|c|c|c|c|c|c|c|}
\hline $\mathrm{pH}$ & $\begin{array}{l}\mathrm{Ec} \times 10^{3 \mathrm{a}} \\
\left(\mathrm{dS} \mathrm{m}^{-1}\right)\end{array}$ & $\begin{array}{c}\mathrm{P} \\
\left(\mathrm{mg} \mathrm{kg}^{-1}\right)\end{array}$ & $\begin{array}{c}\mathrm{K} \\
\left(\mathrm{mg} \mathrm{kg}^{-1}\right)\end{array}$ & $\begin{array}{c}\mathrm{N} \\
(\text { Total) } \\
(\%)\end{array}$ & $\begin{array}{c}\mathrm{Mg} \\
\left(\mathrm{meql}^{-1}\right)\end{array}$ & $\begin{array}{c}\mathrm{Ca} \\
\left(\mathrm{meql}^{-1}\right)\end{array}$ & $\begin{array}{c}\mathrm{Cl} \\
\left(\mathrm{meql}^{-1}\right)\end{array}$ & $\begin{array}{l}\mathrm{OC}^{\mathrm{b}} \\
(\%)\end{array}$ & $\begin{array}{l}S \mathrm{P}^{\mathrm{c}} \\
(\%)\end{array}$ & $\begin{array}{c}\mathrm{CaCO} 3 \\
(\%)\end{array}$ & $\begin{array}{c}\mathrm{HCO} 3 \\
(\%)\end{array}$ & $\begin{array}{c}\text { Sand } \\
(\%)\end{array}$ & $\begin{array}{l}\text { Silt } \\
(\%)\end{array}$ & $\begin{array}{l}\text { Clay } \\
(\%)\end{array}$ \\
\hline 7.60 & 0.60 & 39.3 & 565 & 0.11 & 1.87 & 1.89 & 0.80 & 0.73 & 49.9 & 11.84 & 3.57 & 16 & 44 & 40 \\
\hline
\end{tabular}

${ }^{a} \mathrm{E} c \times 103$, electrical conductivity; ${ }^{\mathrm{b}} \mathrm{OC}$, organic carbon; ${ }^{\mathrm{c}} \mathrm{SP}$, saturation percentage 
formed a discontinuous buffer system together with the gel buffer. A high molecular weight ladder of $250 \mathrm{KD}$ (Fermentas) was used for detection of protein bonds on the gel. Electrophoresis was performed at constant current of $50 \mathrm{~mA}$ in the BioRad electrophoretic apparatus set at $150 \mathrm{~V}$ for 1 hour.

Gels were silver-stained following the silver staining method described by Blum et al. (1987). The gels (fixed in TCA) were incubated for $20 \mathrm{~min}$ three times in 5\% (v/v) methanol, soaked for $1 \mathrm{~min}$ in $40 \mathrm{mg} / \mathrm{l}$ of $\mathrm{Na}_{2} \mathrm{~S}_{2} \mathrm{O} 4$, washed two times in water, and incubated for $20 \mathrm{~min}$ in a $0.2 \%(\mathrm{w} / \mathrm{v}) \mathrm{AgNO}_{3}$ solution containing $0.035 \%(\mathrm{v} / \mathrm{v})$ formamide. For protein coloration, the gels were washed two more times and then soaked in a solution of $3 \%$ (w/v) $\mathrm{Na}_{2} \mathrm{CO}_{3}, 0.035 \%$ (v/v) formamide, and $40 \mathrm{mg} / \mathrm{l}$ of $\mathrm{Na}_{2} \mathrm{~S}_{2} \mathrm{O}_{4}$.

\section{Statistical analysis}

Spectrophotometric protein concentration data are presented as means of three readings from three independent experiments. Significant differences were assessed by Student's $t$ test. Differences were considered to be significant at the $P \leq 0.05$ level.

\section{Result and discussion}

\section{Changes in total soluble proteins}

There were significant differences in soluble stem protein content between the two lines when infected by Sclerotinia sclerotiorum. Soluble protein content in stems of the partially resistant line C71 increased $12 \mathrm{~h}$ and 24 $\mathrm{h}$ post inoculation by Sclerotinia sclerotiorum (to a maximum of 1.3 times). In stems of the susceptible line C146 there was no significant induction in soluble protein content (Fig. 1).

Malencic et al. (2010) also reported that soluble protein content increased in soybean genotypes $12 \mathrm{~h}$ and 24 $\mathrm{h}$ post inoculation by Sclerotinia sclerotiorum. Naglaa and

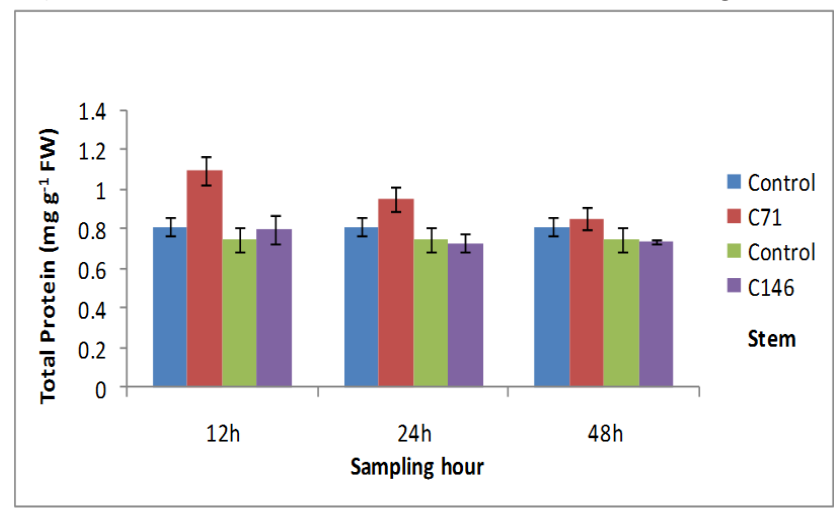

Fig. 1. Levels of soluble proteins in non-infected and Sclerotinia sclerotiorum infected stems of two sunflower lines. Data are means \pm SD of triplicate samples from three independent experiments. Differences were considered to be significant at the $P \leq 0.05$ level
Heba (2011) showed that total soluble protein content in leaves of resistant flax lines increased significantly after powdery mildew invasion. Inoculation with the fungus Sclerotinia sclerotiorum induced a rapid accumulation of stress proteins in tomato plants (Gorovits et al., 2007).

Bacterial and fungal plant pathogens elicit the synthesis of host proteins which restrict the spread of the pathogens to healthy tissue (Datta et al., 1999). Pathogenesis-related proteins are considered stress-related proteins produced in response to infections by viruses, viroids, bacteria and fungi, and are thought to function in the acquired resistance against further infection (Van Loon, 1989). Gnieszka and Iwona (2003) reported that the presence of pathogenesisrelated proteins, such as chitinase and thaumatin, in the tissue infected by pathogens, positively correlates with plant resistance to micro-organisms. However, in contrast to most other types of stress proteins, they accumulate in plant tissues to levels that are easily detectable on gels by general protein stains (Van Loon, 1989). Induction of pathogenesis-related proteins has since been found to be invariably linked to necrotizing infections giving rise to systemic acquired resistance (SAR), and has been taken to be a marker of the induced state (Kessmann et al., 1994).

Changes in electrophoretic patterns of soluble stem proteins in resistant and susceptible sunflower

To check if there were any changes in polypeptide composition between lines, total soluble stem proteins were size-fractionated on SDS-PAGE. Fig. 2 and 3 show the electrophoretic patterns of soluble stem proteins of partially resistant (C71) and susceptible (C146) lines at 12, 24 and $48 \mathrm{~h}$ after inoculation with the fungus Sclerotinia sclerotiorum. A number of proteins accumulated in both susceptible and partially resistant lines after pathogen invasion (Fig. 2 and 3). A rapid accumulation of stress-related, low-molecular-weight proteins was induced in both lines in different pathways. Lanes loaded with soluble proteins from the partially resistant line showed a clear difference between control and infected plants. At 12 and $24 \mathrm{~h}$ post inoculation, soluble proteins with a molecular mass of 27 $\mathrm{kDa}$ accumulated in stem of $\mathrm{C} 71$ infected plants. This response was more pronounced at $12 \mathrm{~h}$ post inoculation and protein band density was high. This polypeptide pattern was detected only in the partially resistant line.

Disease resistance in plants is manifested by limited symptoms, reflecting the inability of the pathogen to grow and spread, and often takes the form of a hypersensitive reaction (HR). Following a HR reaction, systemic acquired resistance leads to the induction of numerous plant genes encoding defense proteins (Ryals et al., 1994). These proteins include structural proteins that are incorporated into the extracellular matrix and participate in the confinement of the pathogen, as well as enzymes of secondary metabolism; for instance, those involved in the biosynthesis of plant antibiotics and pathogenesis-related proteins, which represent major quantitative changes in 
122

soluble protein during a defense response. All have been identified in polyacrylamide gels run either in the absence or in the presence of SDS and stained with general protein stains. Pathogenesis-related proteins usually have low molecular mass (8-50 kDa) (Stintzi et al., 1993). Marcela et al. (2000) isolated a $16 \mathrm{kDa}$ protein from Helianthus annuus flowers that inhibits the germination of Sclerotinia sclerotiorum spores. Raju et al. (2008) reported higher levels of pathogenesis-related proteins in roots and shoots of a resistant cultivar of chickpea than in a susceptible cultivar upon inoculation with the fungus Fusarium oxysporum. Black spot disease in rose also induced accumulation of soluble proteins, particularly 27 and $36 \mathrm{kDa}$ pathogenesisrelated proteins (Suo and Leung, 2002).

Two polypeptide bands, with molecular mass ranging from 55 to $60 \mathrm{kDa}$, were only observed in the control plants and disappeared in the Sclerotinia-inoculated stems of the partially resistant line (Fig. 2). This may indicate that this particular polypeptide was initially sensitive to Sclerotinia sclerotiorum invasion and, hence, disappeared at Sclerotinia treatment over the 12, 24 and 48 h post inoculation. Previous studies have clearly shown that oxidative stress may be triggered when plants encounter an aggressive pathogen (Nanda et al., 2010). Oxidative stress can disrupt normal metabolism by oxidizing DNA, RNA, lipids, and proteins affecting the integrity of cell membranes and inactivating key cellular functions (Singh et al., 2009). So, breakdown of proteins and decrease of pathogenesis related (PR) proteins under oxidative stress are expected. Decline of the $\mathrm{PR}$ proteins level was detected in viral infected tobacco during programmed cell death, known as the hypersensitive response (HR) in plants (Mittler et al., 1998). Malencic et al. (2010) also reported that proteins content influenced in soybean genotypes inoculated by Sclerotinia

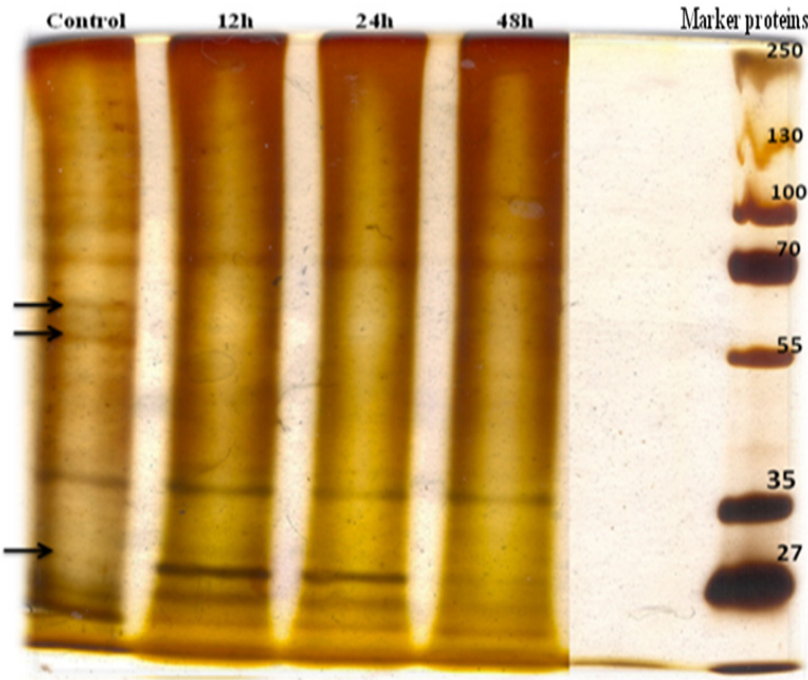

Fig. 2. SDS-PAGE patterns of total leaf soluble protein fractions from a resistant C71 sunflower genotype at 12, 24 and 48 $\mathrm{h}$ post inoculation. The arrows indicate bands which were influenced after Sclerotinia sclerotiorum invasion sclerotiorum. Lee et al. (2006) monitored changes in the rice proteome responding to fungal pathogen Rhizoctonia solani and observed decreased PR proteins associated with abiotic stress.

At 12,24 and $48 \mathrm{~h}$ post inoculation, a new protein band with a molecular mass of $55 \mathrm{kDa}$ appeared in soluble stem proteins of the susceptible line (Fig. 3). The results showed the accumulation of new proteins in the susceptible line and the absence of this band in the partially resistant line.

Certain plant genes are required for susceptibility to plant pathogens. Vogel et al. (2002) analyzed the PMR6 mutant of Arabidopsis and showed that it exhibits enhanced resistance to powdery mildew. Resistance is associated with a recessive, loss-of-function mutation in PMR6. These points suggest that PMR6 might function as a plant disease susceptibility factor rather than as a component of host defense responses. Resistance and susceptibility are opposite sides of the same coin, and the study of disease resistance cannot be conducted without reference to susceptibility.

In conclusion, by using SDS-PAGE the current study revealed that inoculation with the fungus Sclerotinia sclerotiorum induced a rapid accumulation of stress-related proteins in a partially resistant sunflower line. This more rapid response to Sclerotinia sclerotiorum invasion could be partially responsible for the resistance or susceptibility to this pathogen. The findings in this paper provide benefits in the better understanding of Sclerotinia biotic stress and the understanding of stress related physiology in sunflower. These differences between lines, also may point to further pathways in exploring host-pathogen relations which could ultimately lead to selection and production

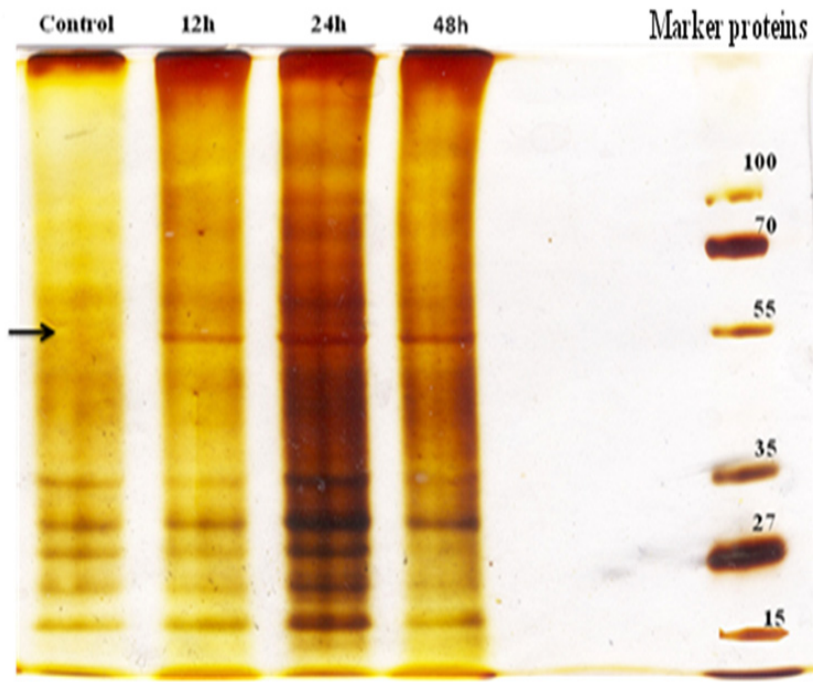

Fig. 3. SDS-PAGE patterns of total leaf soluble protein fractions from a susceptible $\mathrm{C} 146$ sunflower genotype at 12, 24 and $48 \mathrm{~h}$ post inoculation. The arrows indicate bands which were induced after Sclerotinia sclerotiorum invasion 
of new genotypes with higher levels of resistance to Sclerotinia sclerotiorum and also to some other plant pathogens.

\section{Acknowledgements}

The authors gratefully thank the Institute of Biotechnology, Urmia University, Urmia, Iran, for financial support of this work.

\section{References}

Abedi T, Alemzadeh Ab, Kazemeini SA (2011). Wheat yield and grain protein response to nitrogen amount and timing. Austr J Crop Sci 5:330-336.

Agrios GN (1988). Plant Pathology, $3^{\text {rd }}$ Ed. Academic Press Inc., San Diego USA.

Bashan Y, Okon Y, Henis Y (1985). Peroxidase, polyphenol oxidase and phenols in relation to resistance against Pseudomonas syringae pv tomato in Tomato plants. Can J Bot 65:366-372.

Bazzalo ME, Dimarco P, Martinez F, Daleo GR (1991). Indicators of resistance of sunflower plant to basal stalk rot (Sclerotinia sclerotiorum): Symptomatological, biochemical, anatomical, and morphological characters of the host. Euphytica 57:195-205.

Beaudoin-Eagan LD, Thorpe TA (1985). Tyrosine and phenylalanine ammonia-lyase activities during shoot initiation in tobacco callus cultures. Plant Physiol 78:438441.

Blum H, Beier H, Gross HJ (1987). Improved silver staining of plant proteins, RNA and DNA in polyacrylamide gels. Electrophoresis 8:93-99.

Bradford MM (1976). A rapid and sensitive method for the quantitation of microgram quantities of protein utilising the principle of protein-dye binding. Anal Biochem 72:248254.

Datta K, Muthukrishnan S, Datta SK (1999). Expression and function of PR- proteins genes in transgenic plants, 261291 p. In: Datta SK (Ed.). Pathogenesis related proteins in plants. CRC Press, Boca Raton.

Davar R, Darvishzadeh R, Majd A, Gousta Y, Sarrafi A (2010). QTL mapping of partial resistance to basal stem rot in sunflower using recombinant inbred lines. Phytopathol Med 49:330-341.

Dixon RA, Harrison MJ, Lamb CJ (1994). Early events in the activation of plant defense responses. Ann Rev Phytopathol 32:479-501.

Dorrell DG, Huang HC (1978). Influence of Sclerotinia wilt on seed yield and quality of sunflower wilted at different stages of development. Crop Sci 18:974-978.

Frindlender M, Inbar J, Chet I (1993). Biological control of soil borne plant pathogens by a $-1,3$ - glucanase producing Pseudomonas cepacia. Soil Biol Biochem 25:1211-1221.

Garfin DE (1990). One dimensional-gel electrophoresis. Met in Enzymol 182:425-441.
Gnieszka P, Iwona Z (2003). Cold-induced plant resistance to necrotrophic pathogens and antioxidant enzyme activities and cell membrane permeability. Plant Sci 164:1019-1028.

Gorovits R, Akad F, Beery H, Vidavsky F, Mahadav A, Czosnek $H$ (2007). Expression of stress-response proteins upon whitefly-mediated inoculation of tomato yellow leaf curl virus in susceptible and resistant tomato plants. Molec Plant Microbe Interact 20:1376-1383.

Gulya T, Rashid KY, Masireviæ SM (1997). Sunflower diseases, 263-379 p. In: Schneiter AA (Ed.). Sunflower Technology and Production, ASA, CSSA, SSSA, Madison, WI, USA.

Kessmann H, Staub T, Ligon J, Oostendorp M, Ryals J (1994). Activation of systemic acquired disease resistance in plants. Eu J Plant Pathol 100:359-369.

Lee SC, Hwang IS, Choi HW, Hwang BK (2008). Involvement of the pepper antimicrobial protein CaAMP1 gene in broad spectrum disease resistance. Plant Physiol 148:1004-1020.

Lee J, Bricker TM, Lefevre M, Pinson SRM, Oard J (2006). Proteomic and genetic approaches to identifying defenserelated proteins in rice challenged with the fungal pathogen Rhizoctonia Solani. Molec Plant Pathol 7:405-416.

Malencic D, Kiprovski B, Popovic M, Prvulovic D, Miladinovic J, Djordjevic V (2010). Changes in antioxidant systems in soybean as affected by Sclerotinia sclerotiorum (Lib.) de Bary. Plant Physiol Biochem 48:903-908.

Marcela A, Mariana G, Regente C, de la Canal L (2000). A potent antifungal protein from Helianthus annuus flowers is a trypsin inhibitor. Plant Physiol Biochem 38:881-888.

Mittler R, Feng X, Cohen M (1998). Post-transcriptional suppression of cytosolic ascorbate peroxidase expression during pathogen-induced programmed cell death in Tobacco. Plant Cell 10:461-473.

Naglaa AA, Heba IM (2011). Impact of secondary metabolites and related enzymes in flax resistance and or susceptibility to powdery mildew. World J Agric Sci 7:78-85.

Nanda AK, Andrio E, Marino D, Pauly N, Dunand C (2010). Reactive oxygen species during plant-microorganism early interactions. J Integrative Plant Biol 52:195-204.

Price K, Colhoun J (1975). A study of variability of isolates of Sclerotinia sclerotiorum (Lib.) de Bary from different hosts. J Phytopathol 83:159-166.

Raju S, Jayalakshmi SK, Sreeramulu K (2008). Comparative study on the induction of defense related enzymes in two different cultivars of chickpea (Cicer arietinum L.) genotypes by salicylic acid, spermine and Fusarium oxysporum f sp ciceri. Austr J Crop Sci 2:121-140.

Ramanathan A, Samiyappan R, Vidhyasekaran P (2000). Induction of defense mechanism in green gram leaves and suspension cultured cells by Maccrophomina phaseolina and its elicitors. J Plant Diseases Protect 107:245-257.

Rasmussen JB (1991). Systemic induction of salicylic acid accumulation in cucumber after inoculation with Pseudomonas syringae. Plant Physiol 97:1342-1348. 
124

Ryals J, Uknes S, Ward E (1994). Systemic acquired resistance. Plant Physiol 104:1109-1112.

Sackston WE (1992). On a treadmill: breeding sunflowers for resistance to disease. Ann Rev Phytopathol 30:529-551.

Saharan GS, Mehta N (2008). Sclerotinia Diseases of crop plants: biology, eology and disease Management. LXII. Springer-Verlag GmbH, Heidelberg.

Schneiter AA, Miller JF (1981). Description of sunflower growth stages. Crop Sci 21:901-903.

Singh BN, Singh BR, Sarma BK, Singh HB (2009). Potential chemoprevention of N-nitrosodiethylamine-induced hepatocarcinogenesis by polyphenolics from Acacia nilotica bark. Chem-Biol Interact 181:20-28.

Slusarenko AJ, Fraser RSS, Van Loon LC (2000). Mechanisms of resistance to plant diseases. Dordrecht: Kluwer, $620 \mathrm{p}$.

Stintzi A, Heitza T, Prasadb V, Wiedemann-Merdinoglu S, Kauffmanna S, Geoffroya P, Legranda M, Fritiga B (1993). Plant pathogen-related proteins and their role in defense against pathogens. Biochim 75:687-706.
Stoscheck CM (1992). Quantitation of protein. Met Enzymol 182:50-69.

Suo Y, Leung DWM (2002). BTH-induced accumulation of extracellular proteins and black spot disease in Rose. Biol Plantarum 45:273-279.

Van Loon LC (1989). Stress proteins in infected plants, 198237 p. In: Kosuge T and Nester EW (Eds.). Plant-Microbe Interactions, Molecular and Genetic Perspectives, MacGrawHill Publ Comp, New York, USA.

Van Loon LC (1997). Induced resistance in plants and the role of pathogenesis-related proteins. Eu J Plant Pathol 103:753765.

Vogel J, Raab TK, Schiff C, Somerville SC (2002). PMR6, a pectate lyase-like gene required for powdery mildew susceptibility in Arabidopsis. Plant Cell 14:2095-2106.

Zhao J, Wang J, An L, Doerge RW, Chen ZJ, Grau CR, Meng J, Osborn TC (2007). Analysis of gene expression profiles in response to Sclerotinia sclerotiorum in Brassica napus. Planta 227:13-24. 